\title{
The Predictive Power of Preschool Children's Social Behaviors on Their Play Skills
}

\author{
Büşra Ergin ${ }^{1}$, Esra Ergin ${ }^{2}$ \\ ${ }^{1}$ Necmettin Erbakan University, Ahmet Kelesoglu Faculty of Education, Konya, Turkey \\ ${ }^{2}$ Selcuk University, Institute of Social Sciences, Konya, Turkey \\ Correspondence: Büşra Ergin, Necmettin Erbakan University, Ahmet Kelesoglu Faculty of Education, 42090, Konya, \\ Turkey.
}

Received: July 23, 2017

doi:10.11114/jets.v5i9.2601
Accepted: August 15, $2017 \quad$ Online Published: August 17, 2017

URL: https://doi.org/10.11114/jets.v5i9.2601

\begin{abstract}
The aim of this research study is to investigate children's play skills in terms of social behaviours (physical aggression, relational aggression, positive social behaviors, and depressive feelings). The participants in this study consisted of 300 children between 60 and 72 months studying at preschool education institutions. The research data were collected via the "Preschool Social Behaviour Scale-Instructer Form" and the "Play Skills Assessment Scale". Pearson's correlsation analysis and simple linear regression analysis were performed to evaluate the data. The results of the research study indicate that there is a significant positive correlation between children's positive social behaviours and play skills while there is a significant negative relationship between children's play skills and the subscales of physical aggression, relational aggression, and depressive feelings. Besides, the results indicate that children's social behaviours (physical aggression, relational aggression, positive social behaviors and depressive feelings) are predictive of play skills. It can be concluded that $16.8 \%$ of total variance is explained by the subscales "positive social behaviors", $9.6 \%$ is explained by "relational aggression", $2.4 \%$ is explained "physical aggression" and $1.2 \%$ is explained by "depressive feelings".
\end{abstract}

Keywords: preschool, social behavior, play skills

\section{Introduction}

Human beings interact with their environment from birth to death. This interaction is a must requirement by life circumstances. Each individual has to interact with their environment. Individuals who live together in a society have to build correct relationships in order to maintain a sound life. These relationships are also crucial for ensuring the unity, peace and continuance of a society. Social skills underlie healthy relationships between individuals (Samanci \& Ucan, 2017).

Gresham defined social skills in three ways, based on peer acceptance, behavioral perspective, and social validity (Gresham, 1997). Peer acceptance refers to individuals' friendship relationships and it is observed that individuals who receive acceptance from their peers have sufficient social skills (Sucuoglu \& Cifci, 2001). According to the definition in terms of behavioral perspective, social skills are learned behaviors that enable an individual to get positive results and hinder him/her from getting negative reactions (Ergenekon, 2012). In a definition based on social validity, social skills are referred as behaviors that enable an individual to get positive results in different areas such as academic skills and social relationships (Sucuoglu \& Cifci, 2004).

When the literature regarding social skills is reviewed, social behaviors have been associated with several variables (Curran, Wallander \& Farrell, 1985; Bacanli, 1999). Mize \& Abell (2006) reported that socially sufficient children develop more sophisticated skills, act more positively, have more positive relationships with their parents, avoid criticism, and are less controlling towards other children. Peer relationships play an essential role in social skills. Children acquire or consolidate their social skills by means of peer relationships. It has been reported by a study by Mize \& Abell (2006) that socially sufficient children have fewer difficulties in their relationships with peers (Gresham \& Reschly, 1987; Hartup, 1996; Slaski \& Cartwright, 2002; Thompson, 2006; Verschueren, Buyck \& Marcoen, 2001).

The education settings and methods provided especially in early childhood present a variety of models to modify and amend behaviour issues in children and create social interaction opportunities for children and enable them to develop environment-friendly behaviors (Kargi \& Erkan, 2004). One of these methods is play. 
Even though play exists in every moment of life, it is the best way for children especially in the early years of life to discover the world they live in, express the emotions like happiness, anxiety and joy, and express themselves to the people around them. Children learn to discover the environment, imitate the models surrounding them and develop their already existing skills through play (Rae \& Cohen, 1987).

Play contributes to a child's development and education, helps their mental development and physical growth, enables them to conform to society rules, exchange help with other people and show them respect. Besides, it helps the child protect both his/her own rights and his/her friends' rights and learn the ways of not hurting his/her friends. Play is a sum of activities that make it possible for a child to integrate with people with different personality characteristics and discover the life with a different learning method (Gunes, 2011; Kocyigit, Tugluk \& Kok, 2007). The reason for the emphasis on social-emotional development in the research conducted in the literature regarding play is shaping children's social life, which is one of the major needs of children, through play. The child starts to learn the roles in life, keep up with his/her playmates, know them better and have stronger relationships through play (Lowenthal, 1997; Poyraz, 2011; Girmen, 2012).

When the literature is reviewed, many studies have been conducted on the relationship between children's play behaviors and their cognitive skills (e.g. Bergen, 2002; Guney-Karaman, 2009; Peisach \& Hardeman, 1985; Saracho, 1995; Sener, 1996; Yilmaz, 2006), language skills and communication skills (e.g. Craig-Unkefer \& Kaiser, 2002; Kurudayioglu, 2003; McLoyd, 1980; Toret, Ozdemir, Selimoglu \& Ozkubat, 2014; Suhonen, Nislin, Alijoki \& Sajaniemi, 2015). Most studies focused on the relationship between play and social skills (e.g. Christie \& Johnsen, 1983; Denham, Renwick \& Holt, 1991; Farver, Kim \& Lee, 1995; Lester \& Russell, 2010; Mathieson \& Banerjee, 2011; Newton \& Jenvey, 2011; Papatga, 2012; Russ \& Kaugars, 2001; Tannock, 2008; Kocyigit, Yilmaz \& Sezer, 2015). Summarizing the findings of these research studies, one can say that play and children's social development interact with each other. In this scope, this research study aims to investigate children's play skills in terms of social behaviors (physical aggression, relational aggression, positive social behaviors and depressive feelings).

\section{Method}

\subsection{Research Model}

In accordance with the aim of this research, the present study has been conducted on relational screening model.

\subsection{Participants}

The participants in this study were 300 children, 156 girls (52\%) and 144 boys (48\%) between 60 and 72 months studying at preschool education institutions in the city center of Konya during 2016-2017 academic year. As a data collection instrument, the "Play Skills Assessment Scale" was filled out the children's parents and the "Preschool Social Behaviour Scale - Instructer Form" was filled out by their preschool teachers.

\subsection{Data Collection Instruments}

The "Play Assessment Scale" and the "Preschool Social Behaviour Scale - Instructer Form" were used as data collection instruments in the present study.

\subsubsection{The Preschool Social Behaviour Scale-Instructer Form}

The Preschool Social Behaviour Scale - Instructer Form (PSBS-T) developed by Crick, Casas \& Mosher (1997) and adapted into Turkish by Karakus (2008) was used as a data collection instrument. In the first stage, six items lower than .40 were excluded from the 25-item Preschool Social Behaviour Scale - Instructer Form after the factor analysis. When it comes to reliability of the subscales of the original scale, the internal consistency reliability was found high in physical aggression $(\alpha=.94)$, relational aggression $(\alpha=.96)$, positive social behaviors $(\alpha=.88)$, and depressive feelings $(\alpha=.87)$. In the study conducted by Karakus on validity and reliability, reliability of the scale subscales were found to be high: physical aggression $(\alpha=.89)$, relational aggression $(\alpha=.83)$, positive social behaviors $(\alpha=.88)$. The reliability of the subscales of depressive feelings $(\alpha=67)$ was found to be in a sufficient level. This scale consists of 19 items that are aimed to identify physical aggression (6 items), relational aggression (6 items), positive social behaviors (4 items) and depressive feelings (3 items). The items in the Likert type scale are ranked as follows: 1. Not true or almost not true, 2. Not very often, 3. Sometimes, 4. Often, 5. Always or almost always true. Children's scores range between minimum 1 and maximum 5 since the arithmetic mean of the scale scores is taken. As the Likert type scale score rises, it can be said that a child exhibits physical-relational aggression, depressive feelings and positive social behaviors more (Karakus, 2008).

\subsubsection{The Play Skills Assessment Scale}

The Play Skills Assessment Scale developed by Fazlioglu, Ilgaz \& Papatga (2013) was used for the aim of identifying what kind of play skills 6-year-old children have while playing and enabling parents to discover these skills. The scale is a five points Likert type and consists of 27 items. The Cronbach alpha reliability co-efficiency was found to be .93 . 
The reliability co-efficiency was recalculated in this research study to ensure the reliability of the scale measurement and was found to be .88 .

\subsection{Data Collection and Analysis}

The research data were collected from 60-72 months old 300 children included in the present study as participants. The Play Skills Assessment Scale, which was used as a data collection instrument in this study, was filled out by the parents of the participant children while the Preschool Social Behavior Scale - Instructer Form was filled out by their preschool teachers. Statistical package program was used to analyse the data. Pearson's correlation analysis and simple linear regression analysis were performed to evaluate the research data. The significance level was accepted as $\mathrm{p}<.05$.

\section{Findings}

In this section, firstly the findings regarding the relationship between preschool children's social behaviors (physical aggression, relational aggression, positive social behaviors and depressive feelings) and play skills were given. Then whether children's social behaviors (physical aggression, relational aggression, positive social behaviors and depressive feelings) predict their play skills was tested via simple linear regression analysis.

Table 1. Results of the Correlation Analysis Regarding the Relationship between Children's Social Behaviors and Play Skills

\begin{tabular}{llllll}
\hline & & $\begin{array}{l}\text { Physical } \\
\text { Aggression }\end{array}$ & $\begin{array}{l}\text { Relational } \\
\text { Aggression }\end{array}$ & $\begin{array}{l}\text { Positive } \\
\text { Behaviours }\end{array}$ & $\begin{array}{l}\text { Social } \\
\text { Depressive } \\
\text { Feelings }\end{array}$ \\
\hline Play Skills Assessment Scale & $\mathrm{r}$ & -.156 & -.310 & .409 & -.107 \\
& $\mathrm{p}$ & $.007^{*}$ & $.000^{*}$ & $.000^{*}$ & $.043^{*}$ \\
& $\mathrm{n}$ & 300 & 300 & 300 & 300 \\
\hline
\end{tabular}

$\mathrm{p}<.05^{*}$

Table 1 displays there is a significant positive correlation $(\mathrm{r}=.409 ; \mathrm{p}<.05)$ between the Play Skills Assessment Scale mean scores and the mean scores on the "Positive Social Behaviors" subscales of the Preschool Social Behavior Scale Instructer Form. On the other hand, it can be seen that there is a significant negative correlation between the mean scores on the subscales named as "Physical Aggression" ( $r=-.156 ; \mathrm{p}<.05)$, "Relational Aggression" $(\mathrm{r}=-.310 ; \mathrm{p}<.05)$ and "Depressive Feelings" ( $\mathrm{r}=-.107$; $\mathrm{p}<.05)$. Accordingly, as the mean scores for children's positive social behaviors increase, the mean scores for play skills increase, too. However, as the mean scores for physical-relational aggression and depressive feelings decrease, the mean scores for play skills decrease, too.

Table 2. Results of Regression Analysis Regarding the Predictive Power of Children's Social Behaviors on Play Skills

\begin{tabular}{llllll}
\hline Variables & $\mathrm{R}$ & $\mathrm{R}^{2}$ & $\beta$ & $\mathrm{t}$ & $\mathrm{F}$ \\
\hline Physical Aggression & .156 & .024 & -.156 & -2.73 & $7.45^{*}$ \\
Relational Aggression & .310 & .096 & -.310 & -5.63 & $31.72^{*}$ \\
Positive Social Behaviors & .409 & .168 & .409 & 7.74 & $60.03^{*}$ \\
Depressive Feelings & .107 & .012 & -.107 & -1.86 & $3.47^{*}$ \\
\hline
\end{tabular}

$\mathrm{p}<.05^{*}$

According to Table 2, the subscales of the Preschool Social Behavior Scale - Instructer Form named as "Physical Aggression" ( $\left.\mathrm{R}=.156, \mathrm{R}^{2}=.024, \mathrm{~F}=7.45, \mathrm{p}<.05\right)$, "Relational Aggression" $\left.\mathrm{R}=.310, \mathrm{R}^{2}=.096, \mathrm{~F}=31.72, \mathrm{p}<.05\right)$, "Positive Social Behaviors" $\left(\mathrm{R}=.409, \mathrm{R}^{2}=.168, \mathrm{~F}=60.03, \mathrm{p}<.05\right)$ and "Depressive Feelings" $\left(\mathrm{R}=.107, \mathrm{R}^{2}=.012, \mathrm{~F}=3.47, \mathrm{p}<.05\right)$ are found to be a significant predictor variable of children's play skills.

It can be seen that $16.8 \%$ of the total variance regarding play skills is explained by the subscale "Positive Social Behaviors"; $9.6 \%$ is explained by "Relational Aggression"; $2.4 \%$ is explained by "Physical Aggression" and 1.2\% is explained by "Depressive Feelings". In addition, examining the t-test results, it can be stated that the scores on the Play Skills Assessment Scale are explained in a significant level by all the subscales of the Preschool Social Behavior Scale Instructer Form ( $\mathrm{p}<.05)$.

\section{Discussion}

Using play is an effective means of teaching preschool children social skills (Guralnick \& Neville, 1997). Play is essential especially in child development and enables one to observe this natural process in its natural settings. It is emphasized that play has an important role in both preschool children's development and education. Behaviors, knowledge and particularly social skills we need to acquire in our lives are learned naturally during play (Darwish, Esquivel, Houtz \& Alfonso, 2001). For this reason, this research study aims to investigate the play skills of children between 60 and 72 months in terms of social behaviors (physical aggression, relational aggression, positive social behaviors, and depressive feelings).

As emphasized by the research results, it can be seen that there is a significant positive correlation between chidren's mean scores on the Play Skills Assessment Scale and the mean scores of the subscale "Positive Social Behaviors" of the 
Preschool Social Behavior Scale-Instructer Form. There is, on the other hand, a significant negative correlation between children's mean scores on the Play Skills Assessment Scale and the subscales "Physical Aggression", "Relational Aggression", and "Depressive Feelings" of the Preschool Social Behavior Scale - Instructer Form. Accordingly, as children's mean scores for positive social behaviors increase, and mean scores for physical-relational agression and depressive feelings decrease, their mean scores for play skills increase. Another result of the research is that the subscales "Physical Aggression", "Relational Aggression", "Positive Social Beehaviors" and "Depressive Feelings" of the Preschool Social Behavior Scale - Instructer Form are a significant variable in predicting children's play skills.

Christie \& Johnsen (1983) reported in several experimental and relational researches that there is a relationship between social competence and play behaviors. In their study focusing on the social skills of four and five-year-old children, Walsh, Sproule, McGuinness, Trew, Rafferty \& Sheehy (2006) revealed that children who attend a play-enriched education program have higher scores in terms of social skills and thinking skills. In their study investigating the social competence of six-eight years old children who exhibit social nonconformity during a play Licciardello, Harchik \& Luiselli (2008) concluded that group plays with children, peer interaction and teaching of responding to interaction develop social skills in children and increase their self-confidence. The research by Uren \& Stagnitti (2009) revealed that there is a significant and positive relationship between preschool children's play behaviors and social competence and participation to school activities.

In the study aiming to treat six-eight years old six children who have some psychological problems (having inappropriate social relationships for normal development, communication difficulties with other children, acting agressively, shyness and introvertedness, nonconformity etc.), Gorker (2001) developed play treatment group techniques, treated the children by means of play and stated that some children showed recovery. Accordingly, it was observed that children's fears in a group setting diminished and their self-confidence improved. They were interested in different activities, started to socialize, understand others and adapt to the environment. According to a study conducted by Webster-Stratton \& Lindsay (1999), children between four and seven who exhibit nonconformity have significantly poor problem solving and social skills, have less control on themselves and display poor play skills in comparison to children deemed normal. In the study investigating the relationship between the games preschool children played with their peers and their social skills, Gagnon \& Nagle (2004) suggested developing play-based interventions for children who lack social skills and exhibit social nonconformity. Examining the research results, as Durualp \& Aral (2010) stated underlining the importance of learning through play, it can be concluded that preschool education, peer interaction and especially play-based teaching techniques are necessary for children to develop socially and emotionally, act in conformity with the environment and acquire social skills.

\section{Note:}

This research study was presented orally in the Congress of Education Research and Practice in Higher Education held in Istanbul on 19-20 May 2017.

\section{References}

Bacanli, H. (1999). Social skills education. Ankara: Nobel Publishing.

Bergen, D. (2002). The role of pretend play in children's cognitive development. Early Childhood Research and Practice, 4(1), 1-13.

Christie, J. F., \& Johnsen, E. P. (1983). The role of play in social-intellectual development. Review of Educational Research, 53(1), 93-115. https://doi.org/10.3102/00346543053001093

Craig-Unkefer, L. A., \& Kaiser, A. P. (2002). Improving the social communication skills of at-risk preschool children in a play context. Topics in Early Childhood Special Education, 22(1), 3-13. https://doi.org/10.1177/027112140202200101

Crick, N. R., Casas, J. F., \& Mosher, M. (1997). Relational and overt aggression in preschool. Developmental Psychology, 33(4), 579-588. https://doi.org/10.1037/0012-1649.33.4.579

Curran, J. P., Wallander, J. L., \& Farrell, A. D. (1985). Heterosocial skills training. Handbook of social skills training and research, 136-169.

Darwish, D., Esquivel, G. B., Houtz, J. C., \& Alfonso, V. C. (2001). Play and social skills in maltreated and non-maltreated preschoolers during peer interactions. Child abuse \& neglect, 25(1), 13-31. https://doi.org/10.1016/S0145-2134(00)00228-3

Denham, S. A., Renwick, S. M., \& Holt, R. W. (1991). Working and playing together: prediction of preschool social-emotional competence from mother-child interaction. Child Development, 62(2), 242-249. https://doi.org/10.2307/1131000 
Durualp, E., \& Aral, N. (2010). A study on the effects of play-based social skills training on social skills of six-year-old children. Hacettepe University Journal of Education, 39, 160-172.

Ergenekon, Y. (2012). Development of social competences: For children with social skills inadequacy, for prospective teachers and teachers. Ed. Sezgin Vuran. Vize Publishing, Ankara.

Farver, J. A. M., Kim, Y. K., \& Lee, Y. (1995). Cultural differences in Korean-and Anglo- American preschoolers' social interaction and play behaviors. Child Development, 66(4), 1088-1099. https://doi.org/10.2307/1131800

Fazlioglu, Y., Ilgaz, G., \& Papatga, E. (2013). The study for validity and reliability of the evaluation of game skills scale. Trakya University Journal of Social Sciences, 15(1), 239-250.

Gagnon, S. G., \& Nagle, R. J. (2004). Relationships between peer interactive play and social competence in at - risk preschool children. Psychology in the Schools, 41(2), 173-189. https://doi.org/10.1002/pits.10120

Girmen, P. (2012). Children's games in Eskisehir folklore and their role in helping children acquire life skills. National Folklore, 24(95).

Gorker, I. (2001). Children's play therapy group: Assessment of play therapy group with a group of children. New Symposium, 39(1), 9-44.

Gresham, F. M., \& Reschly, D. J. (1987). Dimensions of social competence: Method factors in the assessments of adaptive behavior, social skills and peer acceptance. Journal of School Psychology, 25(4), 367-81. https://doi.org/10.1016/0022-4405(87)90038-0

Gresham, F. M. (1997). Social competence and students with behavior disorders: Where we've been, where we are and where we should go. Education and Training in Mental Retardation and Developmental Disabilities, September, 194-201.

Gunes, H. (2011). Now the game time (3rd Edition). Ankara: Kok Publishing.

Guney-Karaman, N. (2009). The relationship between cognitive styles and play behavior of 5-6 years old kindergarden children. Ankara University Journal of Faculty of Educational Sciences, 42(2), 163-182.

Guralnick, M. J., \& Neville, B. (1997). Designing early intervention programs to promote children's social competence. The effectiveness of early intervention, 579, 610.

Hartup, W. W. (1996). The company they keep: Friendships and their developmental significance. Child Development, 67(1), 1-13. https://doi.org/ 10.2307/1131681

Karakus, A. (2008). The study reliability and validity of preschool social behavior scale teacher form. Unpublished Master Thesis, Marmara University, Institute of Educational Sciences, Istanbul.

Kargi, E., \& Erkan, S. (2004). An investigation of preschool children's problem behaviors (Ankara sample). Hacettepe University Journal of Education, (27), 135-144.

Kocyigit, S., Tugluk, M. N., \& Kok, M. (2007). Play as educational activity in the child's development process. Journal of Kazım Karabekir Education Faculty, (16).

Kocyigit, S., Y1lmaz, E., \& Sezer, T. (2015). The investigating of the relationship among social competence, emotion regulation skills and play skills of 60-72 months old. Hasan Ali Yucel Journal of Education, 12(1), 209-218.

Kurudayioglu, M. (2003). Activities to develop speech and speech skills. Journal of Turkology Researches, 13(13), 287.

Lester, S., \& Russell, W. (2010). Children's right to play: An examination of the importance of play in the lives of children worldwide. Working Paper No. 57. The Hague, the Netherlands: Bernard van Leer Foundation.

Licciardello, C. C., Harchik, A. E., \& Luiselli, J. K. (2008). Social skills intervention for children with autism during interactive play at a public elementary school. Education and Treatment of Children, 31(1), 27-37. https://doi.org/10.1353/etc.0.0010

Lowenthal, B. (1997). Useful early childhood assessment: Play - based, interviews and multiple intelligences. Early child development and care, 129(1), 43-49. http://dx.doi.org/10.1080/030044397012901004

Mathieson, K., \& Banerjee, R. (2011). Peer play, emotion understanding, and socio-moral explanation: The role of gender. British Journal of Developmental Psychology, 29(2), 188-196. https://doi.org/10.1111/j.2044-835X.2010.02020.x

McLoyd, V. C. (1980). Verbally expressed modes of transformation in the fantasy play of black preschool children. Child Development, 51(4), 1133-1139. https://doi.org/10.2307/1129554

Mize, J., \& Abell, E. (2006). Teaching social skills to kids who don't have them. Retrieved February 17, 2006 from http://www.behavioradvisor.com/ Socialskills.html. 
Newton, E., \& Jenvey, V. (2011). Play and theory of mind: Associations with social competence in young children. Early Child Development and Care, 181(6), 761-773. http://dx.doi.org/10.1080/03004430.2010.486898

Papatga, E. (2012). The comparison of the game skills of autistic children with their characteristics of social skills and behaviors. Unpublished Master Thesis, Trakya University, Institute of Social Sciences, Edirne.

Peisach, E., \& Hardeman, M. (1985). Imaginative play and logical thinking in young children. The Journal of Genetic Psychology, 146(2), 233-248. http://dx.doi.org/10.1080/00221325.1985.9914451

Poyraz, H. (2011). Play in preschool education and game examples. (3rd Edition). Ankara: Ani Publishing.

Rae, G., \& Cohen, S. (1987). Growing up with Children. Canada: The Dryden Press.

Russ, S. W., \& Kaugars, A. S. (2001). Emotion in children's play and creative problem solving. Creativity Research Journal, 13(2), 211-219. http://dx.doi.org/10.1207/S15326934CRJ1302_8

Samanci, O., \& Ucan, Z. (2017). Social skill education in children. Journal of Graduate School of Social Sciences, 2l(1), 281.

Saracho, O. N. (1995). The relationship between the cognitive styles and play behaviors of preschool children. Educational Psychology, 15(4), 405-415. http://dx.doi.org/10.1080/0144341950150404

Sener, T. (1996). The Effects of dramatic play and constructive play in perspective taking ability in 4-5 years old children. Unpublished Master Thesis, Ankara University, Institute of Social Sciences, Ankara.

Slaski, M., \& Cartwright, S. (2002). Health, performance and emotional intelligence: An exploratory study of retail managers. Stress and Health, 18(2), 63-68. https://doi.org/10.1002/smi.926

Sucuoglu, B., \& Cifci, I. (2001). Cannot he? Is not he? Teaching social skills for children with mental disabilities. Ankara University Printing House, Ankara.

Sucuoglu, B., \& Cifci, I. (2004). Teaching social skills through cognitive process approach. Kok Publishing. Ankara.

Suhonen, E., Nislin, M. A., Alijoki, A., \& Sajaniemi, N. K. (2015). Children's play behavior and social communication in integrated special day-care groups. European Journal of Special Needs Education, 1-17. https://doi.org/10.1080/08856257.2015.1009707

Tannock, M. T. (2008). Rough and tumble play: An investigation of the perceptions of educators and young children. Early Childhood Education Journal, 35, 357-361. https://doi.org/10.1007/s10643-007-0196-1

Thompson, R. A. (2006). Attachment in early years and effects on later development. 14. National Congress of Psychology, 6-8 September 2006, Hacettepe University, Ankara.

Toret, G., Ozdemir, S., Selimoglu, O. G., \& Ozkubat, U. (2014). Opinions of Turkish parents of children with autism: Autism definition and causes of the autism. Ankara University Faculty of Educational Sciences Journal of Special Education, 15(01), 001-014.

Uren, N., \& Stagnitti, K. (2009). Pretend play, social competence and involvement in children aged 5-7 years: The concurrent validity of the Child - Initiated Pretend Play Assessment. Australian Occupational Therapy Journal, 56(1), 33-40. https://doi.org/10.1111/j.1440-1630.2008.00761.x

Verschueren, K., Buyck, P., \& Marcoen, A. (2001). Self-representations and socioemotional competence in young children: A three-year longitudinal study. Developmental Psychology, 37(1), 126-134.

https://doi.org/10.1037/0012-1649.37.1.126

Walsh, G., Sproule, L., McGuinness, C., Trew, K., Rafferty, H., \& Sheehy, N. (2006). An appropriate curriculum for 45 - year - old children in Northern Ireland: comparing play - based and formal approaches. Early Years, 26(2), 201-221. http://dx.doi.org/10.1080/09575140600760003

Webster-Stratton, C., \& Lindsay, D. W. (1999). Social competence and conduct problems in young children: Issues in assessment. Journal of clinical child psychology, 28(1), 25-43. http://dx.doi.org/10.1207/s15374424jccp2801_3

Yilmaz, E. (2006). The effect of the usage of the musical game activity to gain the numbers and transaction concept for the six aged children who take the education before primary school. Unpublished Master Thesis, Cukurova University, Institute of Social Sciences, Adana.

\section{Copyrights}

Copyright for this article is retained by the author(s), with first publication rights granted to the journal.

This is an open-access article distributed under the terms and conditions of the Creative Commons Attribution license which permits unrestricted use, distribution, and reproduction in any medium, provided the original work is properly cited. 